\title{
The Impacts of Crop Diversity in the Production and Economic Development in Bangladesh
}

\author{
Sirajul Islam ${ }^{1} \&$ Muhammad Rabi Ullah ${ }^{1}$ \\ ${ }^{1}$ Economics Department, Bangladesh University of Business and Technology (BUBT), Mirpur, Dhaka-1216, \\ Bangladesh \\ Correspondence: Sirajul Islam, Bangladesh University of Business and Technology, Rainkhula, Mirpur, Dhaka- \\ 1216. E-mail: sitohin@gmail.com
}

Received: April 6, 2012

doi:10.5539/ijef.v4n6p169
Accepted: May 2, 2012

Published: June 1, 2012

URL: http://dx.doi.org/10.5539/ijef.v4n6p169

\begin{abstract}
The study uses data from 1986 to 2009 about the production of various cereal crops, purposively selected to represent major production trend in Bangladesh before and after introduction of Crop Diversification Program (CDP) in the early 1990's. The paper attempts to identify importance associated with diversified production, based on usage of lands. Bar graphs, pie charts and trend lines are used to represent the trends in production of rice, other cereal crops and yield of crops per acre of land. The yield-land ratio is used to find out the actual growth in production and it is showing upward trends over the years. Per capita agricultural output is shown to get concept about the condition of food security. Here it is clarified that diversification increases the agricultural production as well as helps to grow industries, reduces unemployment, increases the supply of nutrition and protein, import substitution and growth in agricultural GDP thus overall GDP of the country.
\end{abstract}

Government policies and strategies are discussed related with diversified production and having successful CDP program to achieve production targets.

Keywords: diversity, yield-land ratio, per capita output, merits

\section{Introduction}

The practical use of crop diversity refers to the method of crop rotation and fallow land planting and harvesting one type of crop on a specific plot of land one year, and another the next, based on difference in a plant's nutrients need. ("Using Wikipedia,", 2011). That is, in simple words, the cropping diversity means the use of same piece of land to produce different kinds of crops in different seasons.

Malthus (1798) described that the food production increases in Arithmetic mean but population grows in Geometric progression. So it is impossible to keep pace with the agricultural production and increasing population.

According to the World Bank report (2011), the annual growth of agricultural production in Bangladesh was 5.4 per cent in 2010 and 4.12 percent in 2009 by using the gross agricultural- value added approach, the annual growth rate for agriculture value added based on content local currency. In contrarily, the annual population growth rate in Bangladesh in 2010 was 1.12 percent and 1.06 in 2009.

With the increased number of population, the use of lands has been increased in multi-dimensional ways such as production, building's, construction of shelter etc. On one side, the population increases, so does the demand for food and other necessities. The availability of lands for production, on the other side, decreases which may lead to food deficit. In order to meet the increasing demand for food, the government has adopted various programs e.g., the green revolution in early sixties but still then the production could not meet the cent per cent demand for our population. As a result, we have to import food items from the rest of the world.

To fulfill the demand for food, the government of Bangladesh puts emphasis on production of cereal crops, specially rice and wheat. But the over-emphasis on such crops leads to the rise in their production but reduces the production of some other cereals such as vegetables, pulses, species etc.

The reduction in production of such crops leads to dependent on the import of these crops. But such kinds of cereals are the very important sources of protein and calorie and also useful for soil nutrients. These types of crops are also very cheap in money value. 
Realizing the fact government of Bangladesh had taken crop diversification program (CDP) in early 1990's to increase the production of all cereal crops. This paper aims to illustrate the positive impacts of diversified production in Bangladesh economy. The later part of the paper represents the various merits of diversified production in Bangladesh along with an empirical study. Government agricultural policies as well as policies and strategies of fifth-five year plan are discussed in next section. And finally by mentioning limitations recommendation is made for a successful diversification program in Bangladesh.

\section{Literature Review}

Several studies have done on the crop diversity of Bangladesh; different researchers have used different methodologies to analyze different aspects of diversified production in Bangladesh. Metzel and Ateng (1993) collected data from 10 thanas representing major geographical and agro-ecological zones in Bangladesh. The paper attempted to identify problems associated with diversified crops based on farmers' views. They used the regression analysis and Simpson index of diversity as well as Rice-sharing index. The study identified several constraints of diversification in Bangladesh, made some suggestions as well analyze the impacts of NGO's efforts and the degree of diversity in Bangladesh.

Mahmud et al., (1994) aimed at outlining the policies and issues of crop diversification that are likely to influence the growth and sustainability of agricultural production in Bangladesh. They concluded that crop diversification needs to be addressed as part of the broader agricultural development strategy.

Rahman (2004) used the Probit model to analyze the impact of diversified production in Bangladesh. In his study he showed that diversification is positively influenced by the developed infrastructure of a region such as education, experience, farm asset ownership, and non-income ownership of a farmer.

Akanda (2010) had taken secondary data to describe the changes in pattern of cropping along with a forecast of area to be allocated among various crops in 2029-30 and proposed a re-distribution considering probable crop failure, water crisis and change in food habit. He emphasized on diversification in production of crops mainly by focusing the alternative use of lands other than rice in order to have changing pattern of food habit and reducing pressure on ground water.

Rahman (2008) investigated the merit of diversified production in Bangladesh where he showed technical efficiency (TE) and technical change (TC) as principle components of productivity growth.

Hoque (2004) made a long discussion about the crop diversification in Bangladesh. He scrutinized the cropping pattern in Bangladesh, the important aspects of diversification and showed overall picture of diversified cropping in Bangladesh.

Barghouti et al., (2004) treated diversification as a differentiated form of agricultural development and recognized its role to spur sustainable growth in the rural sector. They mainly aimed to outline practical ways to adopt diversification activities. Their study focused how diversified production could remove poverty of a country. They made a six point structure which influences the diversification such as 1) feasibility, 2) policy, 3) infrastructure and markets, 4) research, extension, and training 5) private sector and supply chains, and 6) natural resources. The paper of them closed with the discussion of key investment areas related with this six-point structure to assist diversification thus reduces poverty.

Each of the studies discuss above focused on a particular side of diversification in production but our study analyses the diversification in agricultural production to foster the economic growth by increasing overall production e.g., both agricultural and industrial production.

\section{Methodology}

This paper is based on secondary data. The sources of the data are Bangladesh Bureau of Statistics, Bangladesh Economic Review and World Bank Report. Here, we use time series data from 1986 to 2009 to analyze the impacts of crop diversity in Bangladesh. We simply make effort to present a descriptive analysis.

\subsection{The Crop Diversification Patterns in Bangladesh}

The lands of Bangladesh are classified into three categories such as High, Medium and lowlands. High lands or top lands are such kinds of lands that are not flooded, Medium lands are flooded rarely and low lands are flooded frequently. There are diversified productions in all types of lands. The cropping pattern is based on different types of lands which is summarized by the following table: 


\begin{tabular}{l|l}
\hline Land Type & Cropping Pattern \\
\hline High & 1. Boro - T.Aman - Fallow \\
& 2. Potato - Boro (HYV) - T.Aman \\
& 3. Pulses - Jute - Fallow \\
& 4. Wheat - Kaon - T.Aman \\
& 5. Tomato - Aus - Vegetables \\
\hline Medium & 1. Potato - Boro - T.Aman \\
& 2. Wheat - T.Aman - Pulses \\
& 3. Oilseed - Boro - T.Aman \\
& 4. Boro - T.Aman - Mustard \\
& 5. Tomato - Aus - Vegetable \\
\hline \multirow{2}{*}{ Low } & 1. Potato - Boro B.Aman \\
& 2. Boro - T.Aman - Fallow \\
& 3. Kaon - T.Aman - Fallow \\
& 4. Wheat - Boro - T.Aman \\
& 5. Jute - T.Aman - Fallow \\
\hline
\end{tabular}

The forces that led crop diversification are described for each major pattern as follows:

\begin{tabular}{l|l}
\hline Major Patterns & Forces \\
\hline i. Potato - Boro (HYV) - T.Aman & a. Irrigation facility \\
& $\begin{array}{l}\text { b. Maximum return } \\
\text { c. Land suitability }\end{array}$ \\
\hline ii. Wheat - Kaon - T.Aman & $\begin{array}{l}\text { a. Irrigation facility } \\
\text { b. Credit facility }\end{array}$ \\
& c. Land suitability \\
\hline iii. Pulses - Aus - Vegetables & a. Improving soil fertility \\
& b. Balanced diet \\
& c. Maximum profit \\
\hline iv. Wheat - Aus - T.Aman & a. Irrigation facilities \\
& b. Credit facility \\
& c. Land suitability \\
\hline v. Boro - T.Aman - Fallow & a. Land suitability \\
& b. Demand of cereal foods \\
& c. Improving sol fertility. \\
\hline
\end{tabular}


Rice, in Bangladesh, is grown throughout the year in three distinct cropping seasons both in irrigated, lowland and upland conditions as follows:

\begin{tabular}{l|l}
\hline i) Irrigated conditions & 1. Potato - Kaon - T.Aman \\
& 2. Boro - T.Aman - Fallow \\
& 3. Wheat - Kaon - T.Aman \\
& 4. Potato - Boro - T.Aman \\
& 5. Tomato - Aus - T.Aman \\
& 6. Pulses - Aus - Fallow \\
\hline ii) Lowland conditions & 1. Wheat - T.Aman - Fallow \\
& 2. Boro - T.Aman - Fallow \\
& 3. Potato - Boro - Aus \\
& 4. Aus - T.Aman - Fallow \\
& 5. Kaon - T.Aman - Fallow \\
& 6. Boro (HYV) - Fallow - Fallow \\
\hline iii) Upland conditions & 1. Mustard - Kaon - T.Aman \\
& 2. Potato - Kaon - T.Aman \\
& 3. Spices - T.Aman - Fallow \\
& 4. Wheat - Vegetable - T.Aman \\
& 5. Pulses - Aus - T.Aman \\
& 6. Wheat - Jute - T.Aman \\
\hline
\end{tabular}

Source: Ministry of Agriculture

"The upland crops can only survive for a short period if the root zone remains saturated. Most of the CDP crops cannot sustain growth in saturated soils for more than one or two days. Moreover, high rainfall during critical growth stages badly damages the upland crops. With adequate irrigation, most of the uplands can become highly suitable for diversified crops during the dry season and moderately suitable rice fields during the wet seasons. For this, between two main rice crops some selected upland crops are diversified and are grown throughout the year. In a multiple cropping system, farmers are cultivating two vegetable crops either solely (one short or another long duration crop) or mixed/relay cropping. This has only been possible due to good soil conditions, available irrigation facilities and adequate farmers' knowledge about the vegetable crops and marketing facility etc., which led the farmers to follow crop diversification around other crops"

(Haque, 2004, Pattern of Diversification section, 3)

\subsection{Overall Conditions of Cereal Crops in Bangladesh}

The government had taken Crop Diversification Program in the 1990s. The following table 1 and figure 1 is showing the production of rice and wheat from 1986 to 2009:

Table 1. Total production of rice and wheat from 1986-90 to 2006-09 (thousands MT)

\begin{tabular}{cccccc}
\hline $\begin{array}{c}\text { Rice and } \\
\text { wheat }\end{array}$ & $1986-1990$ & $1991-1995$ & $1996-2000$ & $2001-2005$ & $2006-2009$ \\
\hline Aus & 11467 & 10243 & 8773 & 8906 & 6659 \\
Aman & 32015 & 46039 & 45233 & 54431 & 42926 \\
Boro & 20739 & 33058 & 44397 & 62582 & 64511 \\
Wheat & 4052 & 6521 & 8374 & 7015 & 3165 \\
\hline
\end{tabular}

Source: Bangladesh Bureau of Statistics 


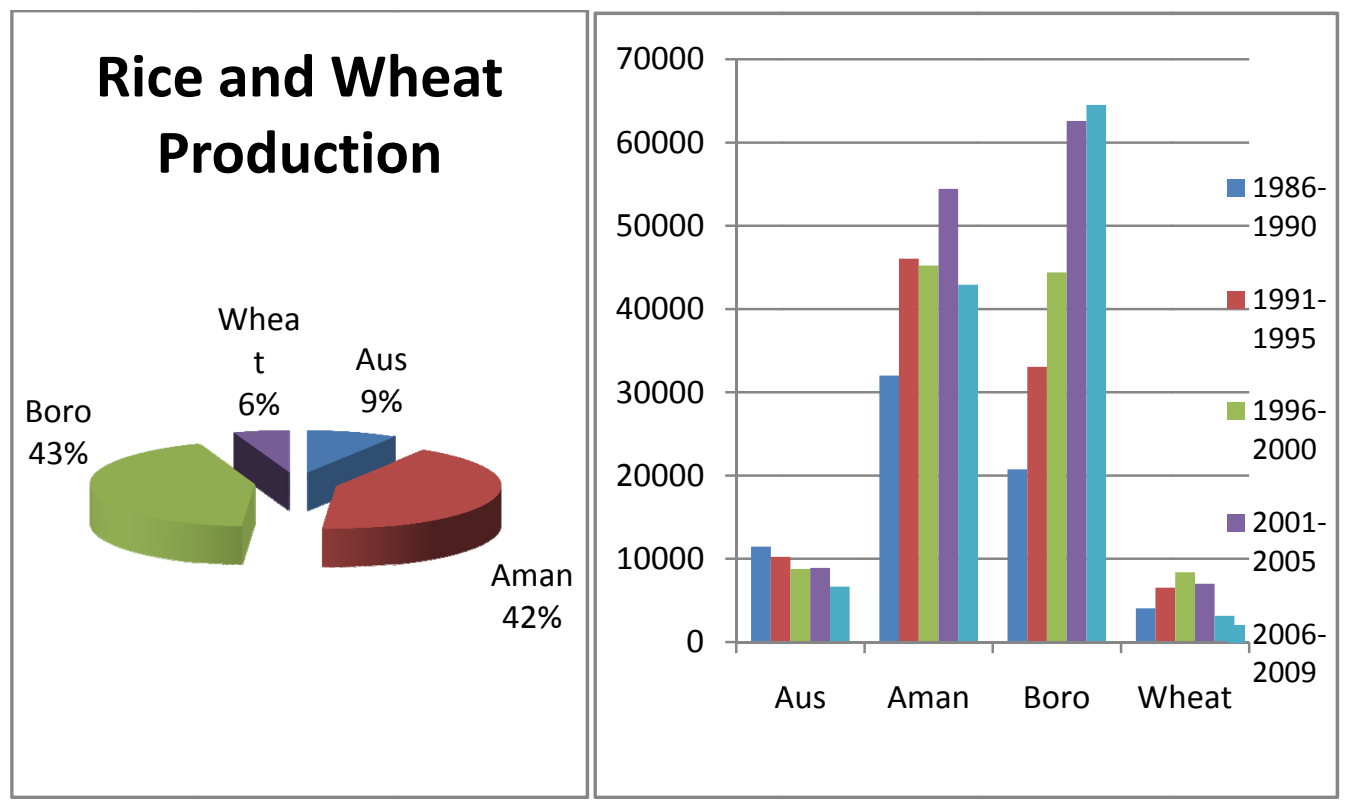

Figure 1. Production of Rice and Wheat from 1986-90 to2006-09

Using total approach we present here the production of rice and wheat in the year of 1986 to 2009.Here, the pie chart shows that the majority of rice production is covered by the Aman, then Boro and Aus, share of wheat production is very small in the pie chart during the period 1986 to 2009. Which implies that rice is the most dominant cereals in Bangladesh. The Bar graph decorated color presents the different rice like Aus, Aman, Boro and also Wheat. Vertical axis of the bar graph represents production of crops and the horizontal axis represents the types of crops. The production of Aus shows decreasing trend within 23 years. Production of Aman has increased from 1986 to 2000 and decreased after 2001. On the other hand, the production of Boro is continuously increasing. The production of wheat has shown a up and down trends. After the diversification program taken in 1990 the production of rice has a stable increasing trends. Wheat production initially increased but after 2000 it began to fall.

The graphical representations of other creal crops with respect to time (using pai chart and bar graph) are discussed below with table-2 and figure 2:

Table 2. Total production of Pulses, Oilseeds, Spices and Potatoes (thousands MT)

\begin{tabular}{cccccc}
\hline Crops & $1986-1990$ & $1991-1995$ & $1996-2000$ & $2001-2005$ & $2006-2009$ \\
\hline Pulse & 2057 & 2623 & 2372 & 1706 & 937 \\
Oilseeds & 1758 & 2333 & 2286 & 1428 & 1339 \\
Spices & 1210 & 1604 & 1755 & 2662 & 4631 \\
Potato & 4500 & 6906 & 10248 & 18358 & 21244 \\
\hline
\end{tabular}

Source: Bangladesh Bureau of Statistics 


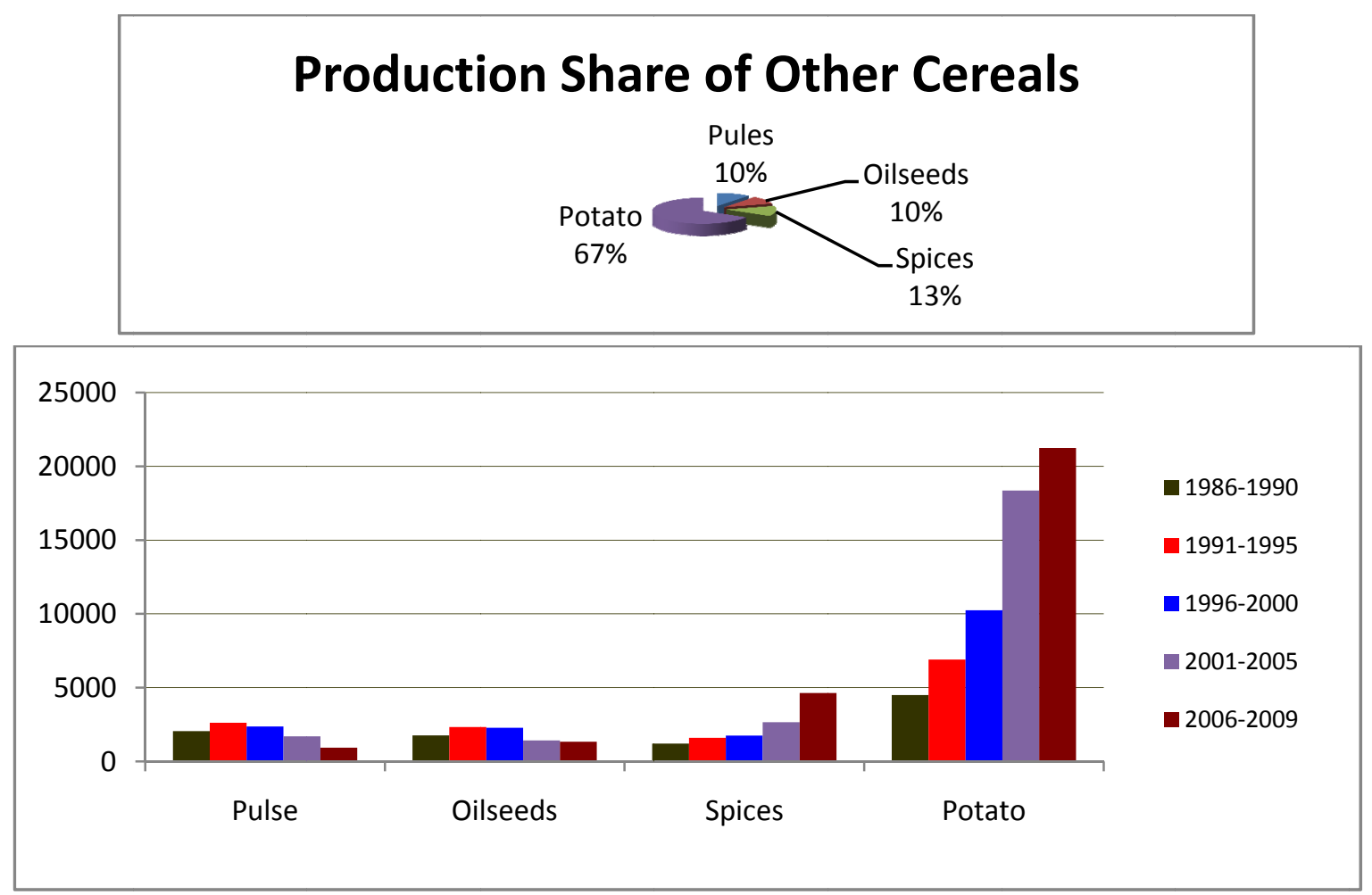

Figure 2. Production of different cereals from 1986-90 to 2006-09

The production of other cereals such as Pulses, Oilseeds, Spices and Potatoes from1986 to 2009 is presented in the pie chart and bar graph. The production of Potatoes increased year after year. From 1986 to 1990 the production of Potatoes was about 5000 metric tons where from 1996 to 2000 it increased to 10,000 metric tons and from 2006 to 2009 it increased above 20,000 metric tons. The productions of Pulses and Oilseeds did not sufficiently increased from 1986 to 1990 and from 1991 to 1995 but decreased between 1996 to 2000 and 2006 to 2009 continuously. Spices, on the other hand, showed increasing trend.

\subsection{The Use of Land and Production of Cereals Other Than Rice and Wheat}

The following graph represents the picture of production due to implementation of Crop diversity program after 1990 , associate data is given in the Table-3:

Table 3. The Use of Lands and Production of Pulses, Oilseeds, Spices and Potatoes

\begin{tabular}{ccc}
\hline Year & Total Acres (Thousands) & Total Production (Thousands MT) \\
\hline $1989-90$ & 3895 & 2339 \\
$1995-96$ & 3775 & 2806 \\
$2000-01$ & 3371 & 4273 \\
$2005-06$ & 2903 & 5807 \\
$2008-09$ & 2831 & 6904 \\
\hline
\end{tabular}

Source: Bangladesh Economic Review-2010 


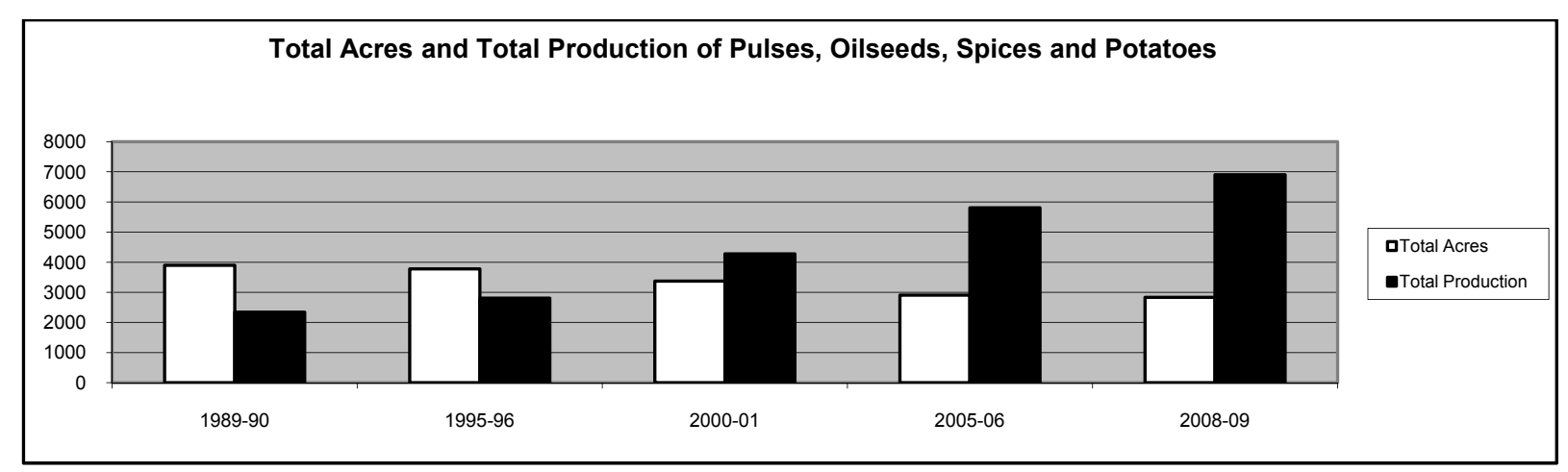

Figure 3. Use of lands and production of minor cereals

The bar graph is representing a true picture of agriculture in Bangladesh. With the time, passing the availability of lands is decreasing which the white bars show and these are becoming smaller. On the other side, the production of lands is showing a upward trend as the production bar graphs are becoming taller. This increasing trend may be due to several factors such as introduction of new production methods but the role of diversified production has also played an important role in the rise in production of such items, even though the acres of lands reduced, mainly because of high population growth.

\subsection{Yield Per Acre of Land}

The output-land ratio or yield-land ratio (which measures the productivity of land) is equal to the level of production divided by the use of lands in acres. Here, the trend line represents the yield-land ratio from 1989-90 to 2008-09 as follows (with Table-4 and 5) and figure-4 and 5:

Table 4. The production of rice and wheat per acre of land

\begin{tabular}{cccc}
\hline Year & $\begin{array}{c}\text { Total land } \\
\text { (Thousand Acres) }\end{array}$ & $\begin{array}{c}\text { Total production } \\
\text { (Thousand Metric Tons) }\end{array}$ & Yield-Land ratio \\
\hline $1989-90$ & 27277 & 18754 & 0.687539 \\
$1995-96$ & 26299 & 19056 & 0.72459 \\
$2000-01$ & 28588 & 26758 & 0.935987 \\
$2005-06$ & 27202 & 27265 & 1.002316 \\
$2008-09$ & 28847 & 32166 & 1.115055 \\
\hline
\end{tabular}

Source: Bangladesh Bureau of Statistics.

Table 5. The production of other cereals per acre of Land

\begin{tabular}{cccc}
\hline Year & Total Land ( Thousand Acres) & Total production (Thousand Metric Tons) & Yield-land ratio \\
\hline $1989-90$ & 3895 & 2339 & 0.600513 \\
$1995-96$ & 3775 & 2806 & 0.743311 \\
$2000-01$ & 3371 & 4273 & 1.267576 \\
$2005-06$ & 2903 & 5807 & 2.000344 \\
$2008-09$ & 2831 & 6904 & 2.438714 \\
\hline
\end{tabular}

Source: Bangladesh Economic Review-2009 


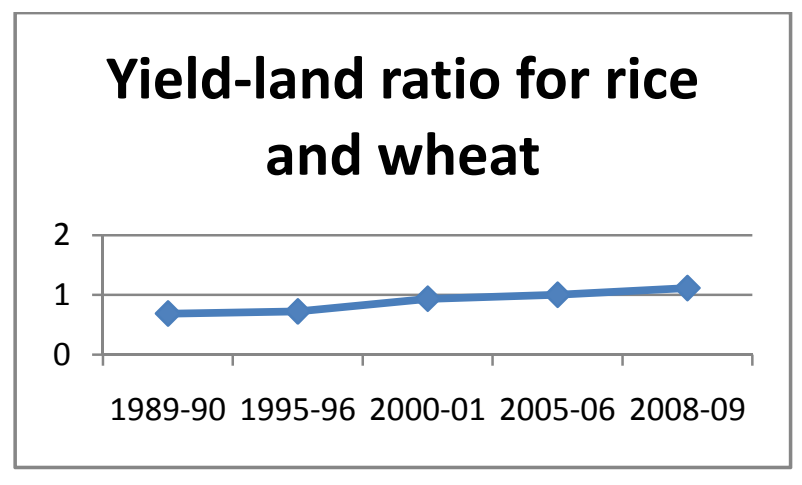

Figure 4. The trend in Yield-land ratio for rice, wheat

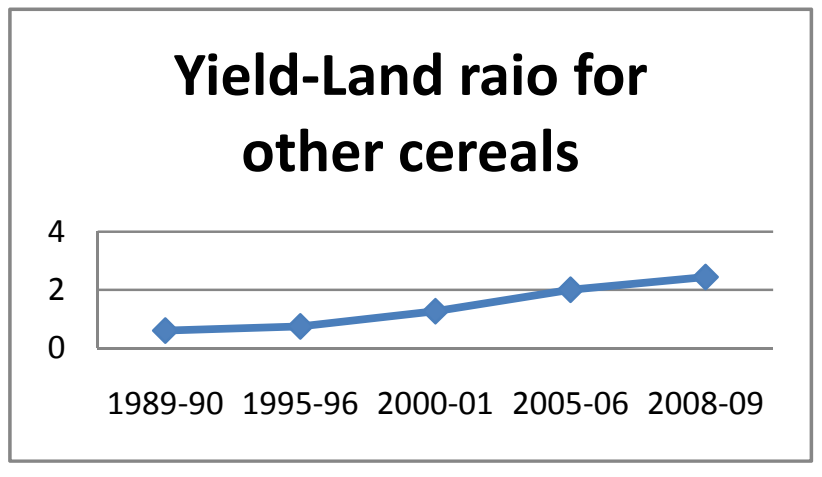

Figure 5. The trend in Yield-land ratio for other cereals

It is clearly visible that, both trend lines are upward slopping, that is the output per acre of land has increased in both cases. The output per acre of land use in rice and wheat production represents quite stable trend. On the other hand, the yield-land ratio for other cereals has represented varying rising trends. After FY 1995-96 this ratio representing a sharp rising trend in compare to 1989-90 till 1995-96 it is mainly due to the successful diversification in cropping.

\subsection{Per Capita Cereals Products}

Per capita cereal food is used here to distinguish the food security situation before and after diversification in cropping has taken in practice, the trend is shown by the following table- 6 and figure 6 :

Table 6. The per capita cereal (rice, wheat, pulses, oilseeds, spices and potato)

\begin{tabular}{cccc}
\hline Year & Total agricultural production (Thousand Metric tons) & Population(Thousand) & Per capita cereal \\
\hline 1990 & 21093 & 105256 & 0.200397 \\
1995 & 21862 & 117487 & 0.18608 \\
2000 & 31031 & 129592 & 0.239452 \\
2005 & 33072 & 140588 & 0.235241 \\
2009 & 39070 & 148692 & 0.262758 \\
\hline
\end{tabular}

Source: UN estimation Report, Bangladesh Bureau of Statistics.

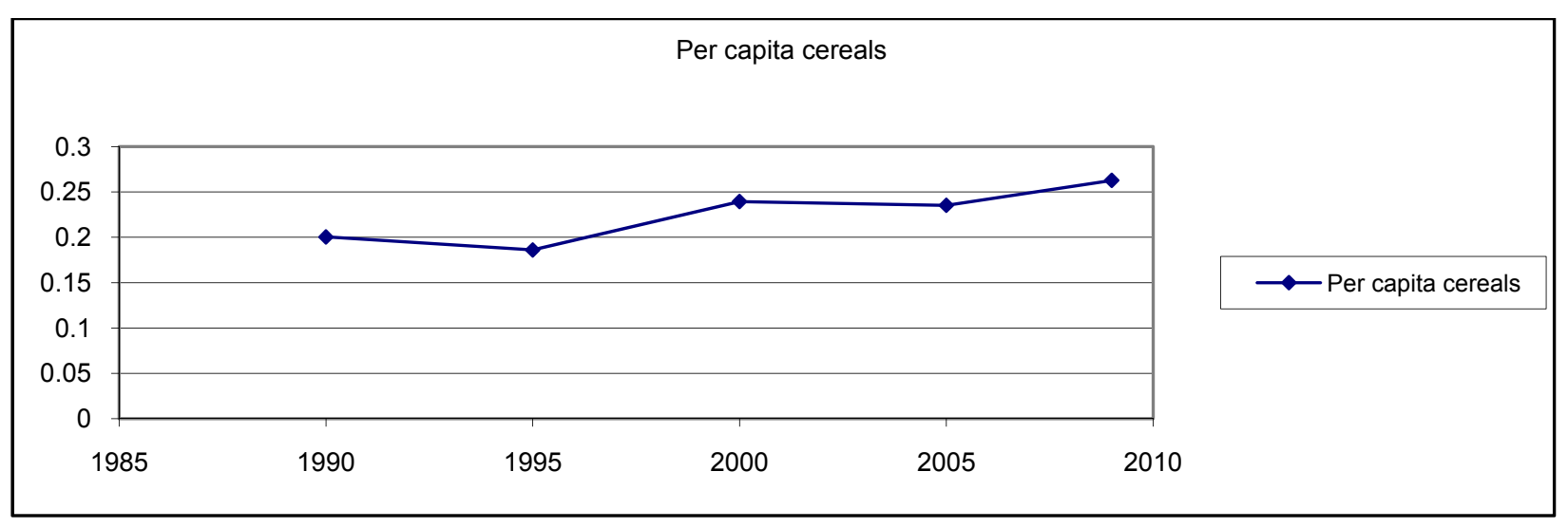

Figure 6. Per capita cereal food

Here, we can see that, per capita cereal was 0.2 Metric tons in 1990, it has fallen down in 1995 and became below 0.19 mainly because of several natural and political disorders. But after that there was an increasing trend till 2000. There was a small lap in 2005, after 2005 to 2009 the line is upward i.e., the per capita output increases which may help to achieve food security. And crop diversification has a positive impact in this respect.

\section{Merits of Diversified Production in Bangladesh}

In our point of view, the diversified cropping is important for the followings: 


\subsection{Controlling Seasonal and Disguised Unemployment}

The nature of agriculture in Bangladesh leads to create seasonal unemployment because the cropping pattern in Bangladesh is based on seasons. After cultivating once, a piece of land is kept fallow. As a result, the farmers or workers in that particular land remain free, that is why the problem of seasonal unemployment arises. On the other hand, the rate of disguised unemployment is very high in agricultural sector in Bangladesh as many workers are working in less productive sectors. Had there been diversified production along with cropping intensity, then both seasonal and disguised unemployment rates will have been reduced markedly.

\subsection{Import Substitution}

The introduction of cropping diversity increases the production of both major and minor cereals. As a result, the import of such products has reduced. That means we are now substituting import of cereals by producing them in our own available lands. It is reported by an international organization - Food and Agriculture Organization (FAO) that the import of cereal crops has been reduced in Bangladesh sharply.

\subsection{Increasing Land Fertility}

It is often said that cultivating the same crop on the same piece of land is not scientific and also not good for the fertility of land, diversification (both in crop and bio) is important for the purpose.

\subsection{Meeting the Demand for Protein and Calorie}

It is said before that the minor cereals are the cheap and important sources of protein and calorie. If we produce both types of cereals by rotation, then it would provide us with sufficient protein and calorie. diversified production is also important to increase employment of the rural needy people as well as to ensure their solvency.

\subsection{Industrialization}

Agriculture and industry are closely related and dependent on each other. Industrial raw materials are supplied by the agriculture on the other hand the industrial outputs are necessary for agricultural development. Many economists viewed that both sectors should developed side by side. So by increasing production in agricultural sector has a positive external effect on industrialization. Diversification in agricultural production increases the scope for expansion in industrial sectors because it helps to intensify the production of both sectors.

\subsection{Economic Growth}

In 2007-08 the contribution of agricultural sectors was accounted 20.83 per cent of total GDP and agricultural items account for about 6.99 per cent of national export earnings. So the growth in agricultural output will help to grow economy rapidly. As the increase in agricultural production helps to get more and more raw materials for industries, so the industrialization would be easy and cost effective. On the other hand import could be substituted by effective industrialization and export could be enhanced through rising both agricultural and industrial production. And there is no alternative of diversified production to foster economic growth through increasing use of limited land resource.

\section{Government Policy Measurements and Strategies}

Crop diversification is one of the major components of crop production policy. For the overall development of crop sector, special emphasis will be given to crop diversification program under the crop production policy. The government policies in this respect are as follows:

- Area under wheat has meanwhile reached at 0.8 million hectare. Given the potential for expanding wheat acreage, efforts will continue to encourage farmers to grow more wheat.

- The production of maize has shown prospective results in last two years. Maize has also gained popularity as human food side by side with the poultry feed. Public sector procurement of maize has been introduced like rice and wheat in order to encourage farmers in maize cultivation. The efforts for increasing area and production of maize will be strengthened.

- The program for increasing area and production of other crops, e.g., potato, pulses, oil seeds, vegetables, fruits and spices will gradually be extended under the crop diversification program

- Production of different cash crops including jute, cotton will be increased and efforts will be made to expand their multiple uses.

- Special development programs will be taken with a view to increasing production of potential crops suitable for the coastal areas and the hill tracts.

\subsection{Fifth Five-Year Plan of Bangladesh Government Regarding Crop Diversity}

Sustainability of high yield and environmental protection remain the principal concern in recent years. Loss of soil fertility followed by unbalanced use of chemical fertilizers, lack of adequate quantity of water in some areas as well as 
their appropriate conservation and management are the major factors causing divergence between potential and actual output of major agricultural commodities. Various studies indicate that the yield potential of the existing HYVs of rice is more than $4 \mathrm{mt} / \mathrm{ha}$, whereas the average yields of most of the other varieties of rice is around $2 \mathrm{mt} / \mathrm{ha}$. Major tasks during the Fifth Five Year Plan will be to address these issues. The specific objectives of the Plan will be to:

a. increase productivity and real income of farming families in rural areas on a sustainable basis;

b. attain self-sufficiency in food grain production along with increased production of other nutritional crops;

c. encourage export of agricultural commodities, particularly vegetables and fruits keeping in view domestic production and need;

d. promote adoption of modern agricultural practices in dry land, wetland and coastal areas;

e. ensure sustained agricultural growth through more efficient and balanced utilization of land, water and other resources; and

f. encourage comparatively large farm to graduate into commercial farming.

\subsection{Policies and Strategies}

In order to achieve the objectives, the strategies/policies will be evolved and adopted to bring about necessary technical change. The following will be the specific policies and strategies:

a. improvement of the quality of seeds, particularly HYV and hybrid seeds and increasing their quantity;

b. development of modern, irrigated and least-risk agriculture with greater reliance on competitive markets through supply of agricultural inputs at low cost; making public investment more effective and keeping it limited to key areas as required to supplement private initiatives;

c. strengthening of the agricultural research and extension systems in order to develop new technologies relating to crop varieties, integrated farming system, organic farming, improved agronomic and agro-processing technologies, and for diffusion of the proven technologies;

d. development and dissemination of ecologically sound and sustainable technologies such as integrated pest management (IPM) techniques, and organic and bio-fertiliser use;

e. increasing profitable production of minor crops and thereby maintaining a balanced crop production and improving the nutritional status of the people;

f. development of suitable technologies in rain-fed, dry land and wetland farming system to enhance the productivity; g. restoration/improvement of soil fertility through better management of the organic matter of soil to improve yields of crops; towards this end, production and use of bio-manure will be encouraged;

h. assistance to small and marginal farmers in forming groups and associations which can (i) enhance production and productivity, (ii) sustain agro-business enterprises on their own, (iii) absorb more credit fund and (iv) adopt/disseminate technologies;

i. participation of NGOs in the agricultural development process;

j. improvement and conservation of plant and genetic resources through collection and conservation of germ plasm;

k. facilitation of access to markets and the promotion of efficient marketing system;

1. formulation of integrated land use policy conducive to optimum use of agricultural resources;

$\mathrm{m}$. implementation of measures to cushion and minimize the damage to agriculture and rural economy brought about by natural calamities;

n. development of the capabilities of rural women and the youth to contribute more to agricultural and rural development;

o. restructuring of the existing institutional set-up to cope with the changed need;

p. development of human resources through education, training and motivation;

q. development and dissemination of appropriate location-specific and cost-reducing production and post-harvest technologies for reduction of post-harvest losses and the removal of transport bottlenecks; and

r. adoption of policies and regulations that will ensure sustainable agricultural development;

\section{Limitations and Recommendations}

Even though there are lots of policies and strategies present but implementation of such policies is a great challenge for the government of Bangladesh. There is a lot of limitations in our country such as weak infrastructure, poor 
transportation facilities, lack of funds, huge bureaucratic behavior, presence of middlemen in agricultural marketing, a strong centralization and low connectivity within the policy makers and the policy takers which make the implementation of any public conducive policy for mass people of our country difficult.

So, to have fruitful policy implication the government of the country should concern to these issues and carefully handle the constraints related with such policies.

\section{Conclusion}

Bangladesh is an agro-based developing nation where majority of the people directly or indirectly depend of agriculture. In 2009 about 48.6 per cent of total labor force was engaged in agricultural sectors. To increase the production of both major and minor cereals crop diversity has a positive impact. Successful diversification in cropping increase the employment opportunities for the marginal rural people, thus increase the income sources as well as solvency of rural people. The development of a country largely depends on industrialization and diversified production helps industries to grow quickly with providing sufficient raw materials. Several field studies showed that the same piece of land is giving more than ten times yield now compared to what it produced twenty years ago; mainly due to the adoption of diversified production in cultivation. Diversification has a positive link in case of provision of food security, improvement of living standard by increasing income of the population through generation of employment opportunities of the huge population and to improve the balance of trade by increasing exports. So, proper initiatives need to be taken by the government and in personal level in such regard.

\section{References}

Ahmed, R., \& Hossain, M. (1990). Developmental impact of rural infrastructure in Bangladesh. IFPRI Research Report, 83. Washington, D.C: International Food Policy Research Institute.

Akanda, A. I. (2010). Rethinking crop diversification under changing climate, hydrology and food habit in Bangladesh. Journal of Agriculture and Environment for International Development, 104(1-2), 3-23.

Asaduzzaman, M. (1989). Feeding our future towns: An overview of urbanization and associated food policy issues. In Food strategies in Bangladesh: Medium and long term perspective invesed. Dhaka, Bangladesh: Bangladesh Planning Commission.

Bangladesh Bureau of Statistics. (2009). The Bangladesh census of agriculture and livestock: 2008-09. Dhaka, Bangladesh: Ministry of Planning.

Barghouti, S., Kane, S., \& Mubarik, A. (2004). Agricultural Diversification for the Poor: Guidelines for Practitioners. The International Bank for Reconstruction and Development Agriculture and Rural Development Department. Washington, D.C: 20433

Crop Diversity. (2011). In Wikipedia, The free encyclopedia Retrieved November 26, 2011 from http://en.wikipedia.org/wiki/Crop_diversity

Hoque, M. E. (2004). Crop diversification in Bangladesh. Dhaka, Bangladesh: Ministry of Agriculture. Retrieved from http://fao.org/docrep/003/x6906e/x6906e04.htm

Mahmud, W., Rahman, S. H., \& Zohir, S. (1994). Agricultural Growth through Crop Diversification in Bangladesh. Food Policy in Bangladesh Working Paper, No. 7. Washington, D.C: International Food Policy Research Institute (IFPRI).

Malthus, T. R. (1798). An essay on the principle of population. (Chapter II, p.18) in Oxford's World Classical reprint.

Metzel, J., \& Ateng, B. (1993). Constraints to Diversification in Bangladesh: A Survey of Farmers' views. The Bangladesh Development Studies, 21(3), 39-71. Crop Diversification in Bangladesh (September 1993).

Ministry of Agriculture. (1989). Crop Diversification Program for the Fifth Five-Year Plan of Bangladesh. Dhaka, Bangladesh: Agriculture Division, MOA.

Ministry of Agriculture. (1999). National Agricultural Policy. Dhaka, Bangladesh: Agricultural Division. MOA. Retrieved from http://www.moa.gov.bd/policy/NAP.pdf

Population growth rate and Agricultural Annual growth rate in Bangladesh. (n.d.). Trading Economics. Retrieved from

http://www.tradingeconomics.com/bangladesh/agriculture-value-added-annual-percent-growth-wb-data.html

Rahman, S. (2008). Whether crop diversification is a desired strategy for agricultural growth In Bangladesh. 82nd Annual Conference. Royal Agricultural College, Cirencester: Agricultural Economics Society. 
Rahman, S. (2004). Determinants of Crop Choices by Bangladeshi Farmers: A Bivariate Probit Analysis. Asian Journal of Agriculture and Development, 5(1).

Appendix:

\section{Case Study}

Recently, we visited a village at Gazipur and met a school teacher there. We had a long discussion with him. He is a land owner and has few bighas of land and uses them in share cropping with local farmers.

He told us that there are three types of land in his village; low land (which are flooded easily), medium high land (not much flooded), and top land (never flooded). In low land, they can produce single crop. In medium high land, two crops (irri and borro) are produced but in top land, they produce three crops (irri, borro and potato). He said that production is almost the same in having a particular product but top land give extra two yields.

In case of fertility, he said that there is a positive impact of diversification but a gap in cultivation is essential for keeping proper micronutrients in the soil, he added. Later, while sharing his experiences, he said that by the grace of Allah the same piece of land is giving more than ten times yield now compared to what it produced twenty years ago. 